\title{
Investigation the complement level in abortive women with antiphospholipid syndrome
} Manal B. Salih*

Mohammed A. Aouda **

Luma R. Lafta*

* Biology dept. - Science College. Thi-Qar Univ. Iraq

** Chemical dept. - Science College. Thi-Qar Univ. Iraq

* Biology dept . . Science College_Thi-Qar Univ. Iraq

\section{$\underline{\text { Abstract }}$}

The present study included 100 women with recurrent miscarriage and more than once due to antiphospholipid antibodies, and who are in the age range between (20-40) years and their comparison with 100 women with normal pregnancy and negative for the disease, by using enzyme-linked Immunosorbent assay (ELISA), for the detection of positive cases of autoimmune disease. The results showed for antiphospholipid antibodies and antibody within the Group (IgM) to the highest rate recorded in the first group (70\%) and age group (31-35) years, and for the Group (IgG), the highest rate recorded in the first group (50\%) and in the age (26-30) years. As can be seen from these results that the percentage of complement in this study was low compared with control.

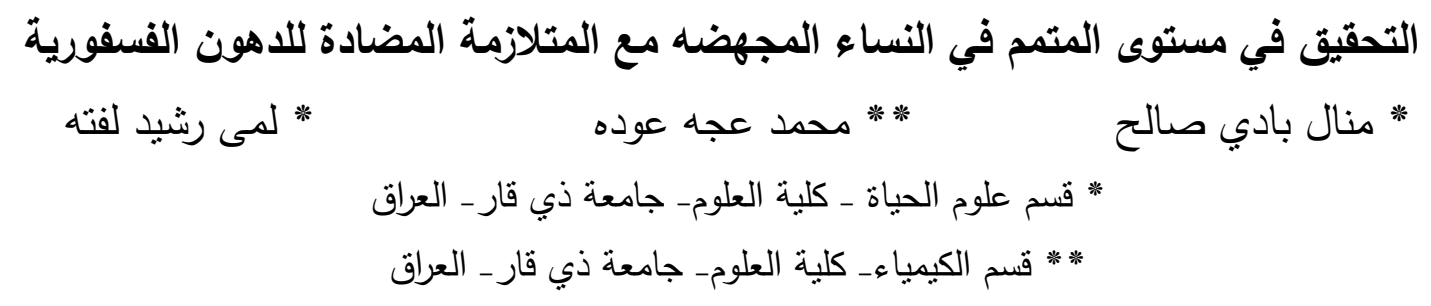

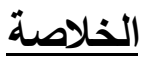

تضمنت الدراسة الحالية ... سيدة تعاني من الإجهاض المنكرر ولأكثر من مره بسبب الأجسام المضادة للفوسفولبيد الضد وممن هن في عمر يتراوح

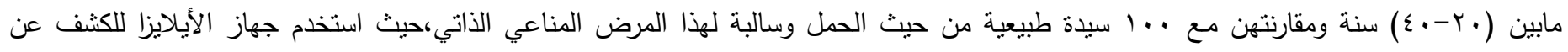

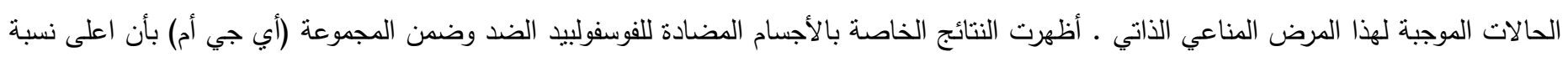

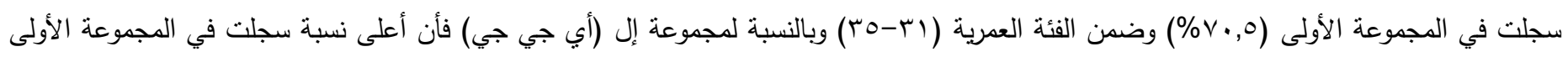

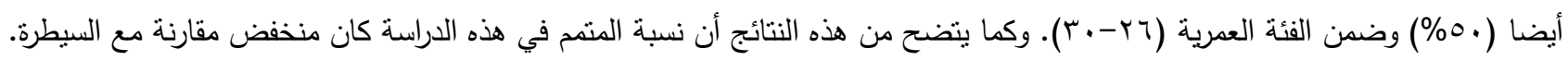

\section{Introduction}

Antiphospholipid antibody syndrome (APS or APLS or), often also Hughes syndrome, is an autoimmune, hypercoagulable state caused by antibodies against cellmembrane phospholipids that provokes blood clots (thrombosis) in both arteries and veins, as well as pregnancy-related complications such as miscarriage, stillbirth, preterm delivery, or severe preeclampsia (Hughes,1983;Hughes, 1985;Asherson\&Cervera,1993).

The syndrome occurs due to the autoimmune production of antibodies against phospholipid (aPL),acellmembranesubstance.The is a generally accepted cause of recurrent pregnancy loss (Hanly , 2003). High levels of antiphospholipid antibodies may account for 3\%-15\% of recurrent miscarriages (Empson et al., 2008). There are 3 distinct APS disease entities :the term "primary antiphospholipid syndrome" is used when APS occurs in the absence of any other related disease (Asherson,1988). APS however also occurs in the context of other autoimmune diseases, such as systemic lupus erythematosus (SLE), in which case the term "secondary antiphospholipid syndrome" is used (Gibson et al., 1997). And in rare cases, APS leads to rapid organ failure due to generalised thrombosis; this is termed "catastrophic antiphospholipid syndrome" (CAPS) and is associated with a high risk of death (Vianna et al., 1994; Asherson et al., 2003; Asherson et al., 2008). Complement is part of the innate immune system and represents one of the effector arms of antibody-mediated immunity (Walport, 2001).In some studies, showed that complement is required for aPLmediated thrombosis and for increased leukocyte 
adhesion to endothelium. In the absence of $\mathrm{C} 3$ or $\mathrm{C} 5$, observed that neither enhanced leukocyte adherence nor increased thrombosis associated with aPL treatment (Silvia et al., 2005). However, recent findings from experimental animals, suggesting that complement activation is involved in pregnancy loss (Xu et al., 2000), led to the investigation of this mechanism in the pathogenesis of APS-related pregnancy morbidity.

\section{Antiphospholipid antibodies Syndrome}

Antiphospholipid Syndrome (APS) is an autoimmune thrombophilic condition that is marked by the presence in blood of antibodies that recognize and attack phospholipid-binding proteins, rather than phospholipid itself (Hughes, 1983).The clinical manifestations of APS include vascular thrombosis and pregnancy complications (Hughes, 1993; Kupferminc et al., 1999), especially recurrent spontaneous miscarriages and, less frequently, maternal thrombosis and many other clinical manifestations may occur (Khamashta et al., 1990; Roubey et al., 1997; Mialdea et al., 2009). Antiphospholipid syndrome (APS) is characterized by venous or arterial thromboses, fetal losses and thrombocytopenia, in the presence of antiphospholipid antibodies (aPL) (Bertolaccini et al., 2006) ,namely lupus anticoagulant (LA), anticardiolipin antibodies (aCL) or antibodies directed to various proteins, mainly beta 2-glycoprotein I $(\beta 2 \mathrm{GPI})$, or in the presence of all three (Miyakis et al., 2006). Although the prevalence of APS in the general population is unknown, the disease affects $5 \%$ to $15 \%$ of patients who have recurrent arterial and venous thrombosis (Piette \& Cacoub, 1998; Hoppensteadt \& Fabbrini , 2008).

\section{Complement and antiphospholipid Syndrome}

Complement is part of the innate immune system and represents one of the effector arms of antibodymediated immunity (Walport, 2001). The complement system is commonly activated in systemic lupus erythematosus (SLE) and is strongly associated with the physiopathology of inflammation, as suggested by the low serum complement concentration with increased deposition at sites of tissue damage. Complementderived inflammatory mediators (anaphylatoxins) such as $\mathrm{C} 3 \mathrm{a}, \mathrm{C} 4 \mathrm{a}$ and $\mathrm{C} 5 \mathrm{a}$ increase vascular permeability, activate platelets(Polley \& Nachman , 1983) and neutrophils, ( Chenoweth \& Hugli ,1980) and promote release of cytokines such as tumor necrosis factor (TNF) a from monocytes, ( Skokowa et al., 2005) with simultaneous induction of systemic inflammation and coagulation. A number of studies on murine models have highlighted how complement activation is essential for aPL-induced pregnancy morbidity(Girardi et al., 2003; Girardi et al., 2004). C5a, the most powerful inflammatory anaphylatoxins, seems to be crucial in clinical manifestation in these models (Girardi et al., 2003). These findings have provided a new insight, suggesting that tissue injury in APS may be caused by a complement-mediated inflammatory process, rather than by thrombosis alone (Salmon et al., 2007).

\section{Methodology}

\section{-Subject and Collection of Blood samples}

One hundred women with recurrent spontaneous abortions positive for antiphospholipid antibody (age range: $20-40$ years) were investigated. The diagnosis was made by the consultant medical staff, which was based on a history inspection, clinical examination.A control sample of 100 fertile women with no previous fetal loss and without known immunologic or rheumatologic diseases is included in the study. From each subject, $5 \mathrm{ml}$ of blood were obtained by venepuncture, using a $5 \mathrm{ml}$ disposable syringe. The blood sample was dispensed in a plain tube, and left for 15 minutes at $4^{\circ} \mathrm{C}$ to clot. Then, it was centrifuged at $3000 \mathrm{rpm}$ for 10 minutes to collect serum. The serum was divided into aliquots $(0.5 \mathrm{ml})$ and stored in the freezer $\left(-20^{\circ} \mathrm{C}\right)$ until use.

\section{Materials}

\section{Biological Materials and Kits}

i. ELISA kits for detection antibodies of six phospholipidepitopes:cardiolipin,phosphoserine,pho sphoglycerol,phosphoethanolamine,phosphatidic acid and phosphoinositol (Aesku, Germany).

ii. Determination of the $\mathrm{C} 3, \mathrm{C} 4$ protein, by radial immunodiffusion plate (Milan-Italy).

\section{Laboratory Investigations}

\section{Antiphospholipid antibody test}

-Anti-cardiolipin IgG and/or IgM measured by standardized, non-cofactor dependent ELISA on 2 or more occasions, not less than 12 weeks apart; medium or high titre (i.e., > $40 \mathrm{GPL}$ or MPL, or > the 99th percentile) and/or-Anti- $\beta 2$ glycoprotein I IgG and/or IgM measured by standardized ELISA on 2 or more occasions, not less than 12 weeks apart; medium or high titre (> the 99th percentile) and/or -Lupus anticoagulant detected on 2 occasions not less than 12 weeks apart according to the guidelines of the International Society of Thrombosis and Hemostasis.

\section{Assay procedure}

* Pipette $100 \mathrm{ml}$ of each patient's diluted serum into the designated micro wells. 
* Pipette 100ml calibrators OR cut-off calibrator and negative and positive controls into the designated wells.

* Incubate for 30 minutes at20-32C $/ 68-89.6 \mathrm{~F}$.

* Wash 3x with $300 \mathrm{ml}$ washing buffer(diluted 1:50).

* Pipette $100 \mathrm{ml}$ conjugate into each well.

* Incubate for 30 minutes at 20-32C $/ 68-89.6 \mathrm{~F}$.

* Wash 3X with $300 \mathrm{ml}$ washing buffer(diluted 1:50).

* Pipette 100ml TMB substrate into each well.

* Incubate for 30 minutes at 20-32C/68-89.6 F,protected from intense light.

* Pipette $100 \mathrm{ml}$ stop solution into each well, using the same order as pipetting the substrate.

* Incubate 5 minutes minimum.

* Agitate plate carefully for $5 \mathrm{sec}$.

* Read absorbance at $450 \mathrm{~nm}$ (optionally $450 / 620 \mathrm{~nm}$ ) within 30 minutes.

Determination of the $\mathrm{C3,C4}$ protein, by radial immunodiffusion plate Principles

The examined protein, diffusing in agarose gel containing a specific antibody will form an immunecomplex, visible as a ring around the well. The ring diameter is direct proportional to the concentration of the analyzed protein. The proportion corresponds to the diffusion time. In fact, at the end $(72 \mathrm{~h})$, the square of diameter will be in linear proportion to the concentration,calibration curve should be constructed, using at least three calibration points. However a reference table is provided showing the relation between any concentration and the end of the procedure.

\section{Procedure}

Remove the plate from its envelope and leave to stand at room temperature for few minutes so that any condensed water in the well can evaporate. Fill the wells with $5 \mathrm{ml}$ of sample and/or controls and wait it has been completely adsorbing before handing the plate. Close the plate and place it in a moist chamber. Wait the required incubation period ( 72 hours. To quicken analysis time it is possible to put the plates in a thermostat.
Based on serum level of Antiphospholipid IgM antibodies, the total patients (100 females) were divided into three main groups, I (55 patients), II (22 patients) and III (4 patients). Their serum APA/IgM levels were 10-30, 31-50and> $50 \mathrm{ng} / \mathrm{ml}$, respectively. These groups were further divided into four age groups (20-25, 26-30, 31-35 and 36-40 years). The age group 31-35 years showed the highest percentage in group I of patients $(70.5 \%)$, for group II it was the age group 2025 years $(28.1 \%)$, while for group III it was the age group 26-30 years $(11.1 \%)$ (Table 1$)$.

Table 1: Observed numbers and percentage frequencies of APA/IgM patients divided by serum level and age

\begin{tabular}{|c|c|c|c|c|c|c|c|}
\hline \multirow{3}{*}{$\begin{array}{l}\text { Age groups } \\
\text { (years) }\end{array}$} & \multirow{3}{*}{$\begin{array}{c}\text { Total } \\
\text { Number }\end{array}$} & \multicolumn{6}{|c|}{$\begin{array}{l}\text { Patients divided by Serum APL/IgM Level (ng } \\
\qquad \mathrm{ml})\end{array}$} \\
\hline & & \multicolumn{2}{|c|}{$\begin{array}{l}\text { Group I } \\
(10-30)\end{array}$} & \multicolumn{2}{|c|}{$\begin{array}{l}\text { Group II } \\
(31-50)\end{array}$} & \multicolumn{2}{|c|}{$\begin{array}{l}\text { Group III } \\
\quad>50\end{array}$} \\
\hline & & No. & $\%$ & $\mathrm{No}$ & $\%$ & No & $\%$ \\
\hline $20-25$ & Tr & 13 & 40.6 & 9 & 28.1 & 0 & 0.00 \\
\hline $26-30$ & רי & 20 & 55.5 & 7 & 19.4 & 4 & 11.1 \\
\hline $31-35$ & IV & 12 & 70.5 & 2 & 11.7 & 0 & 0.00 \\
\hline $36-40$ & 10 & 10 & 66.6 & 4 & 26.6 & 0 & 0.00 \\
\hline Total & $1+$. & 55 & 55.0 & 22 & 22.0 & 4 & 4.0 \\
\hline
\end{tabular}

\section{Groups of Antiphospholipid antibodies/IgG Patients}

Based on serum level of Antiphospholipid IgG antibodies, the total patients (100 females) were divided into three main groups, I (45 patients), II (4 patients) and III (2 patients). Their serum APA/IgG levels were 10-30, 31-50and > $50 \mathrm{ng} / \mathrm{ml}$, respectively. These groups were further divided into four age groups (20-25, 26-30, 31-35 and 36-40 years). The age group 26-30 years showed the highest percentage in group I of patients $(50.0 \%)$, for group II it was the age group 2025 years $(6.2 \%)$, while for group III it was the age group 26-30 years (5.5\%) (Table 2).

\section{$\underline{\text { Results }}$ \\ Groups of Antiphospholipid antibodies/IgM Patients}

Table 2: Observed numbers and percentage frequencies of APA/ IgG patients divided by serum level and age

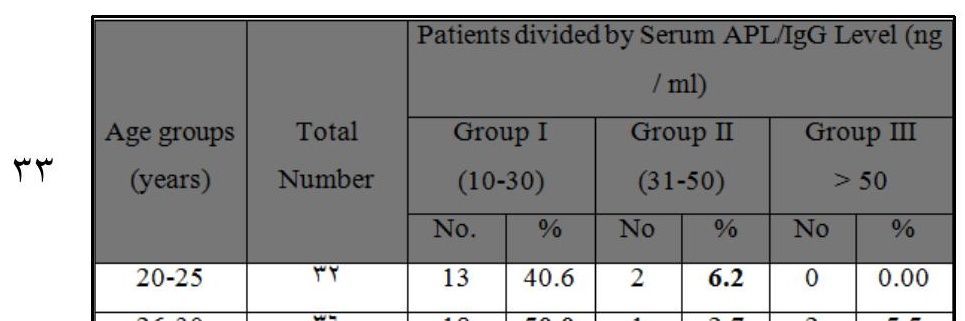




\section{The Third Component of Complement (C3)}

A non-significant decreased serum level of $\mathrm{C} 3$ was observed in total patients, as well as, in all age groups as compared to control in which the difference reached a significant level $(\mathrm{P} \leq 0.01)$ (Table 4-20).

Table 4-20: Total serum level C3 (mean \pm S.E.) of (APA) patients (total and groups) and controls

\begin{tabular}{|c|c|c|c|c|}
\hline $\begin{array}{c}\text { Age Groups } \\
\text { (years) }\end{array}$ & Number & \multicolumn{2}{|c|}{ Mean serum level(mg/dl) C3 \pm S.E. } & LSD \\
\cline { 3 - 4 } & group & Control & Patient & \\
\hline $20-25$ & 15 & $97.47 \pm 5.92$ & $74.05 \pm 16.94$ & 52.87 \\
\hline $26-30$ & 15 & $98.73 \pm 6.48$ & $97.46 \pm 19.81$ & 58.84 \\
\hline $31-35$ & 15 & $95.83 \pm 4.41$ & $91.29 \pm 10.39$ & 33.26 \\
\hline $36-40$ & 15 & $100.99 \pm 3.98$ & $96.99 \pm 11.13$ & 34.82 \\
\hline Total & 60 & $98.26 \pm 2.59$ & $90.66 \pm 7.33$ & 46.3 \\
\hline
\end{tabular}

LSD $\leq 0.01$

\section{The Fourth Component of Complement (C4)}

A significant decreased serum level of $\mathrm{C} 4$ was observed in total patients, as well as, in all age groups (20-25) (26-30) (31-35) (36-40), as compared to control. Such decrease was more pronounced in age group (36-40) $(7.68 \mathrm{mg} / \mathrm{dl})$ and followed by age group $(20-25) \quad(8.54 \mathrm{mg} / \mathrm{dl})$ and age group(26-30) $(11.93 \mathrm{mg} / \mathrm{dl})$ and followed by age group (31-35) (15.56 $\mathrm{mg} / \mathrm{dl})$, in which the difference reached a significant level $(\mathrm{P} \leq 0.05)$ (Table 4-21).

Table 4-21: Total serum level (mean \pm S.E.) of C4 in antiphospholipid antibodies patients (total and groups) and controls

\begin{tabular}{||c|c|c|c|c|}
\hline Age Groups & Number & \multicolumn{2}{|c|}{ Mean serum level C4 \pm S.E. } & LSD \\
\cline { 3 - 4 } (years) & group & Control & Patient & \\
\hline $20-25$ & 15 & $29.23 \pm 1.29$ & $8.54 \pm 0.90$ & 4.66 \\
\hline $26-30$ & 15 & $29.23 \pm 1.29$ & $11.93 \pm 3.30$ & 7.98 \\
\hline $31-35$ & 15 & $29.23 \pm 1.29$ & $15.56 \pm 2.38$ & 10.44 \\
\hline $36-40$ & 15 & $29.23 \pm 1.29$ & $7.68 \pm 0.91$ & 4.65 \\
\hline
\end{tabular}

$\mathrm{LSD} \leq 0.01$

\section{Discussion}

\section{Antiphospholipid antibodies (APA)}

Antiphospholipid antibodies in this result is increased and high significant ( $\operatorname{IgM}, \operatorname{IgG})$ in patients compared with controls. Similar result has been reported by(Dudley and Branch, 1991; Petri, 1993). APA is associated with increased incidence of venous and arterial thromboembolism, thrombocytopenia and recurrent fetal loss(Branch et al., 1985; love et al., 1990), also it is reduced Fibrinolysis and platelet aggregation (Espinosa et al., 2003). Studies done within the last decade have recognized autoimmune factors in patients with recurrent pregnancy loss(Unander et al.,1987; Dudley \& Branch, 1991; Birdsall et al.,1996; Petri, 1993; Ral et al., 1995a). An apparent association between recurrent pregnancy loss and the presence of APL has been suggested by recent prospective clinical studies (Aoki et al.,1993; Pattison et al.,1993; Ral et al.,1995b; Yasuda et al., 1995).Thus, despite some opinions casting doubt on the usefulness of investigating and treating patients having APL and a history of fetal loss, the association of aPL and pregnancy wastage has gained widespread recognition among obstetricians/ gynecologists, other possible aPL pathogenic mechanisms include vascular thrombosis and ischaemia at the site of implantation impairment of endothelial cell receptivity and interference of aPL with syncytiotrophoblasts formation (Rote et al., 1992).

\section{The Third and Fourth Component of Complement}

In this study the level of the Third complement (C3) showed decreased in antiphospholipid antibodies patients as compared with controls. While in fourth complement (C4) showed decreased significant in patients with antiphospholipid antibodies as compared with control.Similar results has been reported by (Oku, 2009), Circulating levels of C' components are lower in APS, also (Holers et al., 2002; Francis , 2006; Shamonki , 2007). Reduced expression of decay 
accelerating factor ( DAF ) greater deposition of C3 and $\mathrm{C} 4$ components in endometrial tissue from aPL-positive women with recurrent miscarriage. Trying to extend their findings in APS associated thrombosis, they studied the dynamics of thrombus formation using a model of in vivo microcirculation thrombus formation monitoring, which had been used by Pierangeli et al. (1995) and found that blocking of C3 activation decreased significantly the size of aPL-induced thrombosis.

\section{Reference}

Aoki, K., Hayashi, Y., Hirao, Y. and Yagami, Y. (1993). Specific antiphospholipid antibodies as a predictive variable in patients with recurrent pregnancy loss. Am. J. Reprod . Immunol., 29: 82-87.

Asherson RA.(1988). A "Primary" antiphospholipid syndrome. J Rheumatol., 15: 1742-1746.

Asherson RA, Cervera R.(1993).Antiphospholipid syndrome, J Invest Dermatol, 100: s21-s27.

Asherson RA, Cervera R, de Groot PG et al (2003). "Catastrophic antiphospholipid syndrome: international consensus statement on classification criteria and treatment guidelines". Lupus .12 (7): 530-4.

Asherson R, Espinosa G, Menahen S, et al.(2008). Relapsing catastrophic antiphospholipid syndrome: Report of three cases. Semin. Arthritis. Rheum. 37: 366-372.

Bertolaccini, M.L., \& Khamashta, M.A. (2006). Laboratory diagnosis and management challenges in the antiphospholipid syndrome. Lupus .15: 172-178.

Birdsall MA, Lockwood GM, Ledger WL, Johnson PM, Chamley LW. (1996). Antiphospholipid antibodies in women having in-vitro fertilization. Hum Reprod., 1: 1185-1189.

Branch, D. W., Scott, J. R., Kochenour, N. K. and Hershgold, E. (1985). Obstetric complications associated with the lupus anticoagulant. $\mathrm{N}$. Engl. J. Med. 313: 1322-1326.

Dudley, D.J \& Branch, D. W. (1991). Antiphospholipid syndrome. A model for autoimmune pregnancy loss. Infernl. Reprod. Med. N. Am., 2:149-164.

Espinosa G, Cervera R, Font J, Shoenfeld Y.( 2003). Antiphospholipid syndrome: pathogenic mechanisms. Autoimmun Rev. 2: 86-93.

Francis J.( 2006). Impaired expression of endometrial differentiation markers and complement regulatory proteins in patients with recurrent pregnancy loss associated with antiphospholipid syndrome. Mol Hum Reprod.12: 435-438.

Gibson GE, Daniel Su WP, Pittelkow MR: (1997). Antiphospholipid syndrome and the skin , J Am Acad Dermatol, 36: 970-982.

Girardi G, Berman J, Redecha P, Spruce L, Thurman JM, Kraus D, et al. (2003). Complement C5a receptors and neutrophils mediate fetal injury in the antiphospholipid syndrome. J. Clin. Invest. 112: 1644-54.

Girardi G, Redecha P, Salmon JE. (2004). Heparin prevents antiphospholipid antibody-induced fetal loss by inhibiting complement activation. Nat Med., 10: 1222-6.

Hanly.(2003). Antiphospholipid syndrome: an overview .CMA J. 168 : 1675-1682.

Holers VM,et al.(2002). Complement C3 activation is required for antiphospholipid antibodyinduced fetal loss. J Exp Med .195: 211-20.

Hoppensteadt DA, Fabbrini N, Bick RL, et al. (2008). Laboratory evaluation of the antiphospholipid syndrome. Hematol Oncol Clin N Am., 22:19-32.

Hughes GR. (1983). Thrombosis, abortion, cerebral disease and the lupus anticoagulant. BMJ. 287:1088-1089.

Hughes GR. (1985). The anticardiolipin syndrome. Clin Exp Rheumatol. 3: 285-6.

Hughes GRV.(1993). The antiphospholipid syndrome: ten years on. Lancet. 342: 341-44.

Khamashta MA, Cervera R, Asherson RA, Font J, Gil A, Coltart DJ, Vázquez JJ, Paré C, Ingelmo M, Oliver J, et al.(1990). Association of antibodies against pho- spholipids with heart valve disease in systemic lupus erythematosus. Lancet., 335: 1541-1544.

Kupferminc, JF, Eldor, A . et al.(1999). Increased frequency of Genetic Thrombophilia in women with complications of pregnancy. New England Journal of Medicine, 340: pp.913.

Love, P. E. and stantoro, S. A. (1990). Antiphospholipid antibodies: anticardiolipin and the lupus anticoagulant in systemic lupus erythematosus(SLE) and in non-SLE disorders. Ann. Int. Med. , 11: 682-688.

Miyakis S, Lockshin MD, Atsumi T et al (February 2006). "International consensus statement on an update of the classification criteria for 
antiphospholipid syndrome (APS)". J. Thromb. Haemost. 4 (2): 295-306.

Mialdea M, Sangle SR, D'Cruz DP.(2009). Antiphospholipid (Hughes) syndrome: beyond pregnancy morbidity and thrombosis. Journal of Autoimmune Diseases., 19:6.

Oku K .(2009). Complement activation in patients with primary antiphospholipid syndrome. Ann Rheum Dis., 68: 1030-5.

Pattison, N. S., Chamley, L. W., Mc Kay, E. J. et al. (1993). Antiphospholipid antibodies in pregnancy, prevalence and clinical associations. Br. J. Obstet. Gynaecol. 100: 909-913.

Petri, M. (1993). Antiphospholipid antibodies and pregnancy loss. In Schlaff, W D and Rock, J. A (eds)., pp. 346-348.

Pierangeli SS, Liu XW, Barker JH, Anderson G, Harris EN. (1995). Induction of thrombosis in a mouse model by $\operatorname{IgG}$, IgM and $\operatorname{IgA}$ immunoglobulins from patients with the antiphospholipid syndrome. Thromb Haemost., 74:1361-7.

Piette J-C, Cacoub P. (1998). Antiphospholipid syndrome in the elderly. Caution. Circulation, 97: 2195-2196.

Polley MJ, Nachman RL.(1983). Human platelet activation by $\mathrm{C} 3 \mathrm{a}$ and $\mathrm{C} 3 \mathrm{a}$ des-Arg. J Exp Med., 158: 603-15.

Ral, R. S., Regan, L., Clifford, K. et al. (1995a). Antiphospholipid antibodies and $\beta 2$ glycoprotein-1 in 500 women with recurrent miscarriage: results of a comprehensive screening approach. Hum. Reprod., 10: 20012005.

Ral, R. S., Clifford, K., Cohen, H and Regan, L. (1995b). High prospective fetal loss rate in untreated pregnancies of women with recurrent miscarriage and antiphospholipid antibodies . Hum. Reprod. 10:3301-3304.

Rote, N. S., Walter, A. and Lyden, T. W. (1992). Antiphospholipid antibodies lobsters or red herrings? Am. J. Reprod. Immunol., 28: 3137.

Roubey RAS, Hoffman M. (1997). From antiphospholipid syndrome to antibodymediated thrombosis. Lancet. 350: 1491-3.

Salmon JE, Girardi G, Lockshin MD. (2007). The antiphospholipid syndrome as a disorder initiated by inflammation: implications for the therapy of pregnant patients. Nat Clin Pract
Rheumatol. 3: 140-7.

Shamonki JM. (2007). Excessive complement activation is associated with placental injury in patients with antiphospholipid antibodies. Am J Obstet Gynecol. 196: 167.e1-e5.

Skokowa J, Ali SR, Felda O, Kumar V, Konrad S, Shushakova N, et al. (2005). Macrophages induce the inflammatory response in the pulmonary Arthus reaction through $\mathrm{G}$ alpha i2 activation that controls $\mathrm{C} 5 \mathrm{aR}$ and $\mathrm{Fc}$ receptor cooperation. J Immunol . 174: 3041-50.

Unander, A. M , Norberg, R., Hahn, L. and Afors, L. (1987). Anticardiolipin antibodies and complement in ninety-nine women with habitual abortion. Am. J. Obstet. Gynecol. 156: 114-119.

Vianna JL, Khamashta MA, Ordi-Ros J, et al.(1994). Comparison of the Primary and secondary antiphospholipid syndrome: an European multicenter study of 114 patients. Am J Med., 96: 3-9.

Walport MJ.(2001). Complement. First of two parts. N Engl J Med. 344:1058-66.

Xu C, Mao D, Holers VM, Palanca B, Cheng AM, Molina H.(2000). critical role for murine complement regulator Crry in fetomaternal tolerance. Science. 287:498-501.

Yasuda, M , Takakuwa, K , Tokunaga, A. and Tanaka, K. (1995). Prospective studies of the association between anticardiolipin antibody and outcome of pregnancy. Obstet .Gynecol., 86: 555-559. 